\title{
INFLUENCE OF SERUM ON SECRETION OF HYALURONIC ACID BY SYNOVIAL CELLS ITS POSSIBLE RELEVANCE IN ARTHRITIS
}

\author{
BY \\ J. R. E. FRASER, G. S. HARRIS, AND B. J. CLARRIS \\ University of Melbourne Department of Medicine, The Royal Melbourne Hospital P.O., \\ Victoria, 3050, Australia
}

Fluid from normal synovial joints contains about $3 \mathrm{mg} . / \mathrm{ml}$. hyaluronic acid (Hamerman and Schuster, 1958). Otherwise, it resembles an ultrafiltrate of plasma, but with a total protein concentration of $13 \mathrm{mg} . / \mathrm{ml}$. (Balazs, Watson, Duff, and Roseman, 1967), which is about one-fifth of that in plasma. With the exception of a tiny fraction bound to hyaluronic acid (Sandson and Hamerman, 1962), the proteins are believed to be identical with those in plasma, although the proportions of the individual proteins differ (Binette and Schmid, 1965). In the inflamed joints of rheumatoid arthritis, the protein concentration rises toward that in plasma. The hyaluronic acid often becomes more dilute, but is much more abundant since the amount of synovial fluid is usually much increased (Balazs and others, 1967). Increased synovial fluid is associated with synovial proliferation in this and other forms of chronic arthritis, suggesting that inflammatory exudation might provide a common factor which stimulates synovial growth and secretion of hyaluronic acid. However, the increased content of hyaluronic acid in inflamed joints might arise also from decreased breakdown or disappearance from the joint, about which little is known, and it would be very difficult to study either aspect of hyaluronic metabolism in intact joints.

A recent study of the influence of human serum upon growth of homologous synovial cells (Clarris and Fraser, 1968a) provided an opportunity to examine the effects of serum upon the secretion of hyaluronic acid by these cells in vitro. Samples from these experiments were stored at $-15^{\circ} \mathrm{C}$. pending the final development of an accurate microassay for hyaluronic acid in cell-culture medium. This paper describes the effects of serum upon the secretory activity of synovial cells in vitro.

\section{Material and Methods}

Growth media were obtained from experiments reported earlier in detail (Clarris and Fraser, 1968a). In each experiment, replicate cultures were established in 20 per cent. foetal calf serum for 24 hours after subculture, and were then randomly allotted for further growth in Medium 199 containing serum, either fresh or previously heat-inactivated for 30 minutes at $56^{\circ} \mathrm{C}$, , at concentrations of 10 and 50 per cent. The experiments were terminated after 46 to 74 hours. Two additional experiments were performed with concentrations of heat-inactivated serum ranging from 5 to 80 per cent. (Table III, below).

Cell numbers were determined at the beginning and end of the experiments from which the following indices were calculated.

\section{Mean generation time:}

$$
\frac{\log _{10} 2 \times \text { time lapse (hrs) }}{\log _{10}\left(\text { final cell count) }-\log _{10}\right. \text { (initial cell count) }}
$$

Mean cell number:

Antilog. $\frac{\log _{10} \text { (final cell count) }+\log _{10} \text { (initial cell count) }}{2}$

A positive expression of growth rate was provided by the reciprocal, 100/mean generation time. Thus a mean generation time of 20 hours would give a growth index of 5 , one of 40 hours an index of $2 \cdot 5$.

Glycosaminoglycans were separated from duplicate samples of growth medium as cetyltrimethylammonium complexes, according to the principles of Scott (1960). The procedure consisted of initial precipitation of the complexes from 2-4 ml. samples onto silica, controlling the conditions to separate the bulk of protein, glucose, and other interfering substances. This was followed by ion exchange for further purification, before solution of the dried residue for measurement by the modified carbazole reaction (Bitter and Muir, 1962). All steps except the last were performed in a single centrifuge tube to avoid errors in transfer or filtration. Control samples of the same media not incubated with cultures were 
included to correct for colour arising from the reagents, residual proteins, and serum glycosaminoglycans. Control and experimental samples contained added serum to the same final volume, which allowed simple derivation of cell-secreted glycosaminoglycans by subtraction, and corrected any tendency to systematic bias in comparing samples with different initial contents of serum. Details will be given elsewhere.

In synovial cultures, the secreted glycosaminoglycan is almost entirely hyaluronic acid (Kling, Levine, and Wise, 1955; Castor, 1957). This is true for the type of culture used in this study (Fraser and McCall, 1965) and has been confirmed in this laboratory by analysis of the products of enzymatic and acid hydrolysis of radioactive cell-secreted glycosaminoglycans. The secretory rates quoted in this paper were calculated from mean cell number, hyaluronic acid estimates, and the duration of the experiments, and expressed as $\mu \mu \mathrm{g}$./cell/day.

\section{Results}

\section{Observations with two concentrations of serum}

Estimations of hyaluronic acid and relevant cell numbers are shown in Table $I$, and the derived rates of cell secretion and growth in Table II. The effects of serum upon cell multiplication have been more extensively analysed elsewhere, but the main effects can be seen in these Tables. Multiplication was significantly more rapid in 50 per cent. serum in all experiments regardless of heat-inactivation. In 10 per cent. serum, multiplication was usually faster in fresh than in heat-inactivated serum.

Hyaluronic acid secretion per cell per day was significantly greater in 50 per cent. than in 10 per cent. serum, being increased by almost half, but there

TABLE I

HYALURONIC ACID AND SYNOVIAL CELL NUMBERS IN DIFFERENT SERA

\begin{tabular}{|c|c|c|c|c|c|c|}
\hline \multirow{3}{*}{$\begin{array}{l}\text { Experiment } \\
\text { No.* }\end{array}$} & \multirow{3}{*}{$\begin{array}{c}\text { Duration } \\
\text { (hrs) }\end{array}$} & \multirow{3}{*}{$\begin{array}{l}\text { Serum } \\
\text { Concentration } \\
\text { per cent. }(v / v)\end{array}$} & \multicolumn{4}{|c|}{ Cultures containing } \\
\hline & & & \multicolumn{2}{|c|}{ (a) Heat-inactivated Serum } & \multicolumn{2}{|c|}{ (b) Fresh Serum } \\
\hline & & & $\begin{array}{c}\text { Hyaluronic } \\
\text { Acid } \\
(\mu \mathrm{g} . / \mathrm{ml} .)\end{array}$ & $\begin{array}{c}\text { Mean Cell } \\
\text { Numbers } \\
\left(\times 10^{-3} / \mathrm{ml} .\right)\end{array}$ & $\begin{array}{c}\text { Hyaluronic } \\
\text { Acid } \\
(\mu \mathrm{g} . / \mathrm{ml} .)\end{array}$ & $\begin{array}{c}\text { Mean Cell } \\
\text { Numbers } \\
\left(\times 10^{-3} / \mathrm{ml} .\right)\end{array}$ \\
\hline 4 & 74 & $\begin{array}{l}50 \\
10\end{array}$ & $\begin{array}{l}4 \cdot 1 \\
2 \cdot 5\end{array}$ & $\begin{array}{l}46 \cdot 0 \\
29 \cdot 7\end{array}$ & $\begin{array}{l}4 \cdot 4 \\
2 \cdot 1\end{array}$ & $\begin{array}{l}46 \cdot 4 \\
39 \cdot 3\end{array}$ \\
\hline 6 & 71 & $\begin{array}{l}50 \\
10\end{array}$ & $\begin{array}{l}9 \cdot 4 \\
4 \cdot 4\end{array}$ & $\begin{array}{l}56 \cdot 4 \\
45 \cdot 6\end{array}$ & $\begin{array}{l}9 \cdot 2 \\
4 \cdot 9\end{array}$ & $\begin{array}{l}62 \cdot 0 \\
48 \cdot 8\end{array}$ \\
\hline 7 & 46 & $\begin{array}{l}50 \\
10\end{array}$ & $\begin{array}{l}7 \cdot 5 \\
2 \cdot 4\end{array}$ & $\begin{array}{l}62 \cdot 8 \\
44 \cdot 6\end{array}$ & $\begin{array}{l}8 \cdot 0 \\
4 \cdot 2\end{array}$ & $\begin{array}{l}60 \cdot 1 \\
50 \cdot 1\end{array}$ \\
\hline 9 & 46 & $\begin{array}{l}50 \\
10\end{array}$ & $\begin{array}{l}6 \cdot 0 \\
4 \cdot 0\end{array}$ & $\begin{array}{l}87 \cdot 1 \\
65 \cdot 8\end{array}$ & $\begin{array}{l}5 \cdot 9 \\
3 \cdot 6\end{array}$ & $\begin{array}{l}81 \cdot 8 \\
69 \cdot 2\end{array}$ \\
\hline 10 & 46 & $\begin{array}{l}50 \\
10\end{array}$ & $\begin{array}{l}5 \cdot 9 \\
3 \cdot 0\end{array}$ & $\begin{array}{l}31 \cdot 4 \\
26 \cdot 9\end{array}$ & $\begin{array}{l}5 \cdot 5 \\
3 \cdot 7\end{array}$ & $\begin{array}{l}36 \cdot 7 \\
27 \cdot 4\end{array}$ \\
\hline
\end{tabular}

*See Clarris and Fraser (1968a) for full details of cell numbers.

TABLE II

RATES OF SYNOVIAL CELL SECRETION AND GROWTH DERIVED FROM DATA IN TABLE I

\begin{tabular}{|c|c|c|c|c|c|c|c|}
\hline \multirow[b]{2}{*}{ Serum } & \multirow{2}{*}{$\begin{array}{l}\text { Experiment } \\
\text { No. }\end{array}$} & \multicolumn{3}{|c|}{ Secretion of Hyaluronic Acid ( $\mu \mu \mathrm{g} . /$ cell/day) } & \multicolumn{3}{|c|}{ Growth Index } \\
\hline & & $\begin{array}{l}\text { (a) In } 10 \text { per cent. } \\
\text { Serum }(v / v)\end{array}$ & $\begin{array}{l}\text { (b) In } 50 \text { per cent. } \\
\text { Serum }(v / v)\end{array}$ & $\begin{array}{l}\text { Difference } \\
(b-a)\end{array}$ & $\begin{array}{l}\text { (a) In } 10 \text { per cent. } \\
\text { Serum }(v / v)\end{array}$ & $\begin{array}{l}\text { (b) In } 50 \text { per cent. } \\
\text { Serum }(v / v)\end{array}$ & $\begin{array}{l}\text { Difference } \\
(b-a)\end{array}$ \\
\hline \multirow[t]{2}{*}{$\begin{array}{l}\text { Heat- } \\
\text { inactivated }\end{array}$} & $\begin{array}{r}4 \\
6 \\
7 \\
9 \\
10\end{array}$ & $\begin{array}{l}27 \\
28 \\
28 \\
31 \\
58\end{array}$ & $\begin{array}{l}29 \\
49 \\
62 \\
36 \\
90 \\
\end{array}$ & $\begin{array}{r}+2 \\
+21 \\
+34 \\
+5 \\
+32\end{array}$ & $\begin{array}{l}1 \cdot 08 \\
1 \cdot 62 \\
1 \cdot 77 \\
1 \cdot 76 \\
1 \cdot 66\end{array}$ & $\begin{array}{l}2 \cdot 79 \\
2 \cdot 48 \\
3 \cdot 92 \\
3 \cdot 52 \\
3 \cdot 15\end{array}$ & $\begin{array}{l}+1.71 \\
+0.86 \\
+2.15 \\
+1.76 \\
+1.49\end{array}$ \\
\hline & Means & $34 \cdot 4$ & $53 \cdot 2$ & $+18 \cdot 8$ & $1 \cdot 58$ & $3 \cdot 17$ & $+1 \cdot 59$ \\
\hline \multirow[t]{2}{*}{ Fresh } & $\begin{array}{r}4 \\
6 \\
7 \\
9 \\
10\end{array}$ & $\begin{array}{l}17 \\
30 \\
44 \\
27 \\
70\end{array}$ & $\begin{array}{l}31 \\
44 \\
69 \\
37 \\
78 \\
\end{array}$ & $\begin{array}{l}+14 \\
+14 \\
+25 \\
+10 \\
+8\end{array}$ & $\begin{array}{l}2 \cdot 17 \\
1 \cdot 89 \\
2 \cdot 49 \\
2 \cdot 08 \\
1 \cdot 78\end{array}$ & $\begin{array}{l}2 \cdot 82 \\
2 \cdot 87 \\
3 \cdot 64 \\
3 \cdot 12 \\
3 \cdot 62\end{array}$ & $\begin{array}{l}+0.65 \\
+0.98 \\
+1.15 \\
+1.04 \\
+1.84\end{array}$ \\
\hline & Means & $37 \cdot 6$ & $51 \cdot 8$ & $+14 \cdot 2$ & $2 \cdot 08$ & $3 \cdot 21$ & $+1 \cdot 13$ \\
\hline \multicolumn{2}{|c|}{ Grand Means } & $36 \cdot 0$ & $52 \cdot 5$ & $+16 \cdot 5^{*}$ & $1 \cdot 83$ & $3 \cdot 19$ & $+1 \cdot 36^{* *}$ \\
\hline
\end{tabular}


were no significant differences in fresh or heatinactivated serum. The degree of increased secretory activity also varied greatly between experiments. Since each was done with different specimens of serum, further studies were undertaken in a range of concentrations of single samples of serum.

\section{Observations in a range of serum concentrations}

The results are shown in Table III. There were again increases in secretory activity and growth rates with higher concentrations of serum. Secretory activity was present when cell growth was nearly stationary, and seemed to reach a maximum in 20-40 per cent. serum, but there was clearly no simple first-order relationship in the degree of these changes. Regression analysis failed to establish any formal pattern, and it was felt that the matter was too complex to pursue further with the present techniques.

\section{Discussion}

These findings indicate that serum not only stimulates synovial cell multiplication, but also stimulates the rate of hyaluronic acid secretion, at least in the early stages of a subculture cycle. The increase in hyaluronic acid secretion cannot be attributed to provision of more substrate for its synthesis, since the required glucose and glutamine are abundant in both serum and Medium 199. The action of serum must therefore arise in some other way. In other circumstances, the prior treatment of the serum can profoundly alter cell growth (McCall and Fraser, 1966; Clarris and Fraser, 1968a), but the slight differences in 10 per cent. fresh and heat-inactivated serum in this study were not reflected in the secretory rates.

The stimulating effect of serum upon secretion of hyaluronic acid contrasts with the findings of Castor (1959). He found no change in secretion by mature, non-proliferating synovial cultures in serum concentrations ranging from 5 to 50 per cent., whereas complete removal of serum was apparently followed by increased secretion. A number of observations have been made about the relationship of glycosaminoglycan secretion to changes in cell growth occurring spontaneously or induced by other means. Grossfeld (1962) has stated that production of hyaluronic acid and cell growth run parallel in cultures of normal fibroblasts, but are inversely related in cultures of Rous sarcoma. Daniel, Dingle, and Lucy (1961) found that cobalt-tolerant rat dermal fibroblasts grew at equal rates in 5 to 20 per cent. serum, but apparently secreted less hyaluronic acid as the serum concentration was raised. Castor and Fries (1961) found no consistent relationship between hyaluronic acid secretion and the spontaneous changes in growth rate which occur during the culture cycles of synovial cells. On the other hand, Morris and Godman (1960) found a direct relationship between secretion and growth of rat dermal fibroblasts in successive phases of a subculture cycle in one growth medium, but some dissociation of secretion and growth in another medium designed to stimulate growth.

Whether the secretory response to serum is simply related to growth rates has not been clearly decided, but such a relationship would be in keeping with the increased density of fibroblasts and outpouring of ground substance which follow vascular exudation in the early stages of wound and fracture repair. In these circumstances, hyaluronic acid has been identified as a major glycosaminoglycan (Antonopoulos, Engfeldt, Gardell, Hjertquist, and Solheim, 1965).

The isolation of synovial cells in culture might seem far removed from conditions within the parent joint, but the identification of collagen fibres (Castor and Muirden, 1964) and a hyaluronic gel (Clarris

TABLE III

SYNOVIAL CELL SECRETION AND GROWTH DURING 72 HOURS IN SEVERAL SERUM CONCENTRATIONS

\begin{tabular}{|c|c|c|c|c|c|c|c|}
\hline \multirow{2}{*}{$\begin{array}{c}\text { Experiment } \\
\text { No. }\end{array}$} & \multirow{2}{*}{$\begin{array}{l}\text { Serum* } \\
\text { Concentration } \\
\text { per cent. }(v / v)\end{array}$} & \multirow{2}{*}{$\begin{array}{c}\text { Initial Cell } \\
\text { Count } \\
\left(\times 10^{-3} \mathrm{ml} .\right)\end{array}$} & \multirow{2}{*}{$\begin{array}{c}\text { Final Cell } \\
\text { Count } \\
\left(\times 10^{-3} / \mathrm{ml} .\right)\end{array}$} & \multirow{2}{*}{$\begin{array}{c}\text { Mean Cell } \\
\text { Number } \\
\left(\times 10^{-3} / \mathrm{ml} .\right)\end{array}$} & \multicolumn{2}{|c|}{$\begin{array}{l}\text { Hyaluronic Acid } \\
\text { Secretion }\end{array}$} & \multirow{2}{*}{$\underset{\text { Index }}{\text { Growth }}$} \\
\hline & & & & & $(\mu \mathrm{g} . / \mathrm{ml})$. & $(\mu \mu \mathrm{g} /$ cell/day $)$ & \\
\hline 1 & $\begin{array}{r}5 \\
10 \\
20 \\
40 \\
80\end{array}$ & $38 \cdot 3$ & $\begin{array}{r}39 \cdot 8 \\
74 \cdot 7 \\
105 \cdot 6 \\
123 \cdot 7 \\
99 \cdot 6\end{array}$ & $\begin{array}{l}39 \cdot 0 \\
53 \cdot 5 \\
63 \cdot 6 \\
68 \cdot 8 \\
61 \cdot 8\end{array}$ & $\begin{array}{l}2 \cdot 7 \\
4 \cdot 9 \\
7 \cdot 0 \\
7.6 \\
6 \cdot 4\end{array}$ & $\begin{array}{l}23 \\
31 \\
37 \\
37 \\
35\end{array}$ & $\begin{array}{l}0 \cdot 075 \\
1 \cdot 34 \\
2 \cdot 03 \\
2 \cdot 35 \\
1 \cdot 92\end{array}$ \\
\hline 2 & $\begin{array}{r}5 \\
10 \\
20 \\
40 \\
80\end{array}$ & $39 \cdot 5$ & $\begin{array}{r}34 \cdot 5 \\
53 \cdot 8 \\
115 \cdot 5 \\
130 \cdot 8 \\
107 \cdot 3\end{array}$ & $\begin{array}{l}37 \cdot 0 \\
46 \cdot 1 \\
67 \cdot 5 \\
71 \cdot 9 \\
65 \cdot 1\end{array}$ & $\begin{array}{l}3 \cdot 2 \\
5 \cdot 3 \\
7 \cdot 2 \\
9 \cdot 7 \\
9 \cdot 0\end{array}$ & $\begin{array}{l}29 \\
38 \\
36 \\
45 \\
46\end{array}$ & $\begin{array}{r}-0.25 \\
0.62 \\
2 \cdot 15 \\
2 \cdot 40 \\
2 \cdot 00\end{array}$ \\
\hline
\end{tabular}

*Heat-inactivated 
and Fraser, 1968b) around these cells in culture indicates that the cells generate a micro-environment not unlike their natural habitat as shown, for example, by Castor (1960) and the two situations are thus not so remote as they appear at first sight. It is therefore proposed that interstitial exudation of serum is a simple common factor which can contribute to the increased hyaluronic acid in inflamed joints by induction either of cellular hyperplasia or greater secretory activity.

\section{Summary}

The hyaluronic acid content of growth media from cultures of human synovial cells grown in human serum was studied by chemical extraction and assay. Highly significant associations were found between serum concentration and secretory rates for hyaluronic acid, and between serum concentration and cell growth rates, although there was no clear evidence of a direct association between secretory and growth rates.

It is suggested that the raised concentrations of serum constituents found in the synovial fluid in chronic arthritis might be responsible in part for the cellular proliferation and increased synovial hyaluronic acid which commonly occur in disease of joints.

This work was made possible by grants from the Arthritis and Rheumatism Council for Research in Great Britain and the Commonwealth, the Australian Rheumatism Council, and the National Health and Medical Research Council of Australia. We are grateful to Professor Evan Williams for regression analyses, and to Mrs. C. Flanders for technical assistance.

\section{REFERENCES}

Antonopoulos, C. A., Engfeldt, B., Gardell, S., Hjertquist, S.-O., and Solheim, K. (1965). Biochim. biophys. Acta (Amst.), 101, 150 (Isolation and identification of the glycosaminoglycans from fracture callus).

Balazs, E. A., Watson, D., Duff, I. F., and Roseman, S. (1967). Arthr. and Rheum., 10, 357 (Hyaluronic acid in synovial fluid. I. Molecular parameters of hyaluronic acid in normal and arthritic human fluids).

Binette, J. P., and Schmid, K. (1965). Ibid., 8, 14 (The proteins of synovial fluid. A study of the alpha ${ }_{1} /$ alpha $_{2}$ globulin ratio).

Bitter, T., and Muir, H. M. (1962). Analyt. Biochem., 4, 330 (A modified uronic acid carbazole reaction).

Castor, C. W. (1957). Proc. Soc. exp. Biol. (N.Y.), 94, 51 (Production of mucopolysaccharides by synovial cells in a simplified tissue culture medium).

(1959). Arthr. and Rheum., 2, 259 (The rate of hyaluronic acid production by human synovial cells studied in tissue culture).

(1960). Ibid., 3, 140 (The microscopic structure of normal human synovial tissue).

- and Fries, F. F. (1961). J. Lab. clin. Med., 57, 394 (Composition and function of human synovial connective tissue cells measured in vitro).

and Muirden, K. D. (1964). Lab. Invest., 13, 560 (Collagen formation in monolayer cultures of human fibroblasts).

Clarris, B. J., and Fraser, J. R. E. (1968a). Aust. J. exp. Biol. med. Sci., 46, 107 (Some factors influencing the reactions of human synovial cells in vitro with fresh homologous and autologous serum).

_ (1968b). Exp. Cell Res., 49, 181 (On the pericellular zone of some mammalian cells in vitro).

Daniel, M. R., Dingle, J. T., and Lucy, J. A. (1961). Ibid., 24, 88 (Cobalt-tolerance and mucopolysaccharide production in rat dermal fibroblasts in culture).

Fraser, J. R. E., and McCall, J. F. (1965). Ann. rheum. Dis., 24, 351 (Culture of synovial cells in vitro).

Grossfeld, H. (1962). Nature (Lond.), 196, 782 (Production of hyaluronic acid in tissue culture of Rous sarcoma).

Hamerman, D., and Schuster, H. (1958). J. clin. Invest., 37, 57 (Hyaluronate in normal human synovial fluid).

Kling, D. H., Levine, M. G., and Wise, S. (1955). Proc. Soc. exp. Biol. (N.Y.), 89, 261 (Mucopolysaccharides in tissue cultures of human and mammalian synovial membrane).

McCall, J. F., and Fraser, J. R. E. (1966). Ann. rheum. Dis., 25, 52 (Cytoplasmic spreading of human synovial cells in culture. III. The diverse effects of normal human serum). 
Morris, C. C., and Godman, G. C. (1960). Nature (Lond.), 188, 407 (Production of acid mucopolysaccharides by fibroblasts in cell cultures).

Sandson, J., and Hamerman, D. (1962). J. clin. Invest., 41, 1817 (Isolation of hyaluronateprotein from human synovial fluid).

Scott, J. E. (1960). In "Methods of Biochemical Analysis", ed. D. Glick, vol. 8, p. 145. Interscience Publishers, New York.

\section{L'influence du sérum sur la sécretion de l'acide hyaluronique par les cellules synoviales}

\section{RÉSUMÉ}

La teneur en acide hyaluronique des milieux de culture de cellules synoviales humaines cultivées dans du sérum humain a été determinée après l'extraction chimique. Des associations hautement significatives ont été vues entre la concentration sérique et la sécretion d'acide hyaluronique, et entre la concentration sérique et la prolifération cellulaire, malgré qu'il n'y avait pas de preuves évidentes d'une association directe entre le taux de sécretion et la multiplication.

Il est suggéré que les concentrations élevées des constituants du sérum trouvés dans le liquide synovial de l'arthrite chronique pouvait être responsable en partie de la prolifération cellulaire et de l'augmentation de l'acide hyaluronique de la synoviale qui a lieu couramment dans les maladies articulaires.
La influencia del suero en la secreción de acido hialurónico por las células sinoviales

\section{SUMARIO}

El contenido de ácido hialurónico de medios de cultivo de células sinoviales humanas, en suero humano, fue estudiado por extracción química y ensayo. Se descubrieron relaciones altamente significativas entre la concentración de suero y los promedios secretorios del ácido hialurónico, y entre la concentración de suero y los promedios de crecimiento de las células, si bien no hubo evidencia clara de una asociación directa entre los promedios secretorios y los de crecimiento.

Se sugiere que las elevadas concentraciones de los componentes séricos hallados en el liquido sinovial en la artritis crónica, quizá sea responsable, en parte, de la proliferación celular y del aumento del ácido hialurónico sinovial que ocurre comunmente en las enfermedades de las articulaciones. 